\section{Changing Sex Ratios in Diabetes}

SIR,-Dr. W. A. Nicholson (20 November, p. 465) reports an increase in the proportion of male diabetics aged 50 years and over in the second of two consecutive decades ending in 1967. We have completed a similar survey of patients attending the diabetic clinic at the Mater Misericordiae Hospital, Dublin.

Patients were classified in groups according to age at onset of diabetes-namely, at 15 years of age or less; between 15 and 45 years; and at 45 years or over. The Table

\begin{tabular}{|c|c|c|c|c|c|c|}
\hline \multicolumn{3}{|c|}{ Age at Diagnosis of Diabetes } & \multicolumn{2}{|c|}{$1951-60$} & \multicolumn{2}{|c|}{$1961-70$} \\
\hline & & & Men & Women & Men & Women \\
\hline 45 years or over & $\cdots$ & . & $\begin{array}{c}117 \\
(32 \cdot 8 \%)\end{array}$ & $\begin{array}{c}239 \\
(67 \cdot 2 \%)\end{array}$ & $\begin{array}{c}377 \\
(41.9 \%)\end{array}$ & $\begin{array}{c}522 \\
(58.1 \%)\end{array}$ \\
\hline
\end{tabular}

illustrates the sex distribution among diabetics diagnosed at 45 years of age or older in the two decades 1951 to 1960 and 1961 to 1970 . The proportion of men diagnosed at 45 years or over rose from $32.8 \%$ in the first decade to 41.9 in the second-an increase of $9.1 \%$. The figures (allowing for differences in method) are similar to Dr. Nicholson's figures of $25.9 \%$ for men at 50 years and over in the first decade and $38.2 \%$ in the second-an increase of $12.3 \%$. The number of men diagnosed at

\section{Specimens from Female Genital Tract}

SIR,-We note with interest the microbiological findings in the female genito-urinary tract described by Dr. W. H. Hughes and Mr. J. M. Davies (13 November 1971, p. 424). We have been carrying out a similar but more restricted investigation in Malawi on groups of African women who are: (1) pregnant or immediately postpartum; (2) healthy and of menstrual age; (3) attending a sterility clinic. Some of our results are summarized and compared in the Table with selected results from the Hughes and Davies's London survey. etc., men in the older age group in both surveys, together with the less sharp increase in the number of women, supports the view ${ }^{1}$ that a change in the sex ratio has occurred among maturity-onset diabetics.-We are,

\section{Mater Misericordiae Hospital,}

M. I. DRURY

F. J. TIMONEY 1 Malins, J. M., Fitzgerald, M. G., and Wall, M.

able to assess the incidence of $N$. gonorrhoeae found in fresh swabs only from a Gram film: probably therefore we have underestimated it. Nevertheless, our clinical impression of the incidence of gonorrhoea is such that even if it were practicable to mount a routine screening programme here it would not be worthwhile. The effort and money put into such a programme would be prohibitively costly for any country. A much smaller sum spent in tracing contacts of established cases more vigorously than at present would have a much greater return.-We are, etc.,

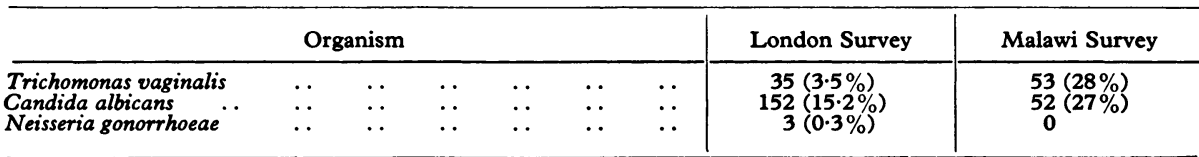

Total patients examined: London 1,000; Malawi 191.

Whatever the causes, and there are probably many, the incidence of Trichomonas vaginalis and Candida albicans is much higher in the Malawian women. We were

\section{Neurological Disease and Folate Deficiency}

SIR,-I should like to record a case of folate deficiency anaemia causing myelopathy.

A woman, aged 63 , was admitted with a history of depression with anxiety of about four years' duration. She was known to be anaemic, and her anaemia had been treated with iron by her own doctor but with only limited success. Recently she had been getting weak in her legs, stayed in bed a great deal, and was complaining of numbness in her feet and legs. Her appetite was poor but her weight loss was negligible.

Central Pathological Laboratory,

R. A. TOZER
50 years or over in his clinic increased from 60 in the first decade to 165 in the second, an increase of $175 \%$, while in our clinic male cases diagnosed at 45 years or over increased from 117 in the first decade to 377 in the second-an increase of $219.6 \%$. In both surveys the increase in the number of women was much less. At the Hartlepool Clinic female diabetics increased from 172 to 262, an increase of $52.3 \%$, and in Dublin from 239 to 522 -an increase of $118.4 \%$.

The marked increase in the proportion of spinal cord due to pernicious anaemia was made.

Investigations showed: Haemoglobin $\mathbf{8 \cdot 2}$ g/100 ml; R.B.C. $2,300,000 / \mathrm{mm}^{3}$; W.B.C. $5,600 / \mathrm{mm}^{3}$; P.C.V. $28 \%$; M.C.H.C. $31 \%$; M.C.V. $117 \mu^{3}$; serum iron $156 \mu \mathrm{g} / 100 \mathrm{ml}$; saturation of iron $91 \%$; total iron binding capacity $171 \mu \mathrm{g} / 100 \mathrm{ml}$; platelets $264,000 /$ $\mathrm{mm}^{3}$; serum $\mathrm{B}_{12} 300 \mathrm{pg} / \mathrm{ml}$; and serum folate $0.6 \mathrm{ng} / \mathrm{ml}$.

The bone marrow was mildly megaloblastic with hyperactive erythropoiesis and increased iron storage. Myelopoiesis was active with giant metamyelocytes and hypersegmented polymorphs.

Treatment was started with hydroxocobalamin, but there was no improvement haematologically or neurologically within 10 days. Reticulocyte response was $2 \%$. After receiving the results of $B_{12}$ and folate, treatment was started with folic acid $10 \mathrm{mg}$ t.d.s. and hydroxocobalamin was stopped. Her haemoglobin went up to $10 \mathrm{~g} / 100 \mathrm{ml}$ in 15 days, reticulocyte response was $12 \%$, and physically her improvement was remarkable. Her legs became stronger, the numbness disappeared, no sensory sign was detected but tendon jerks remained brisk and the plantars were upgoing.

It is generally accepted that folate deficiency does not cause neurological disease. ${ }^{2}$ But Grant, Hoffbrand, and Wells ${ }^{3}$ showed that there was a definite association between folate deficiency and neurological disorders. Anand described a case of folate deficiency causing peripheral neuropathy. ${ }^{4}$ Hansen et $a l .{ }^{5}$ reported a 50-year-old epileptic man who had been treated with anticonvulsants and developed atrophy of muscles and loss of cutaneous sensibility. He died four months later from pneumonia and at necropsy lesions were found in cerebellum, spinal cord, and peripheral nerves. Thus there is some definite evidence to suggest that folate deficiency causes not only depression, anxiety, and irritability, but also neurological manifestations.

I would like to thank Dr. B. K. Samtani for his permission and suggestion to report this case.

-I am, etc.,

Department of Geriatric Medicine,

M. AHMED

St. Mary's Hospital,

Kettering, Northants

1 Cecil-Loeb, Textbook of Medicine, ed. P. B. Becil-Loeb, Textbook of Medicine, ed. P. B.

2 De Gruchy, G. C., Clinical Haematology in Medical Practice, 3rd edn., p. 138. Edinburgh, Blackwell, 1970 Blackwell, 1970. Hoffbrand, A. V., and Wells,
D. G., Lancet, 1965, 2, 763.

4 Anand, M. P., Scottish Medical fournal, 1964, 9, 388. 5 Hansen, H. A., Nordqvist, P., and Sourander, P.,
Acta Medica Scandinavica, 1964, 176, 243.

\section{Collecting Vesicle Fluid}

On examination she was sensible but depressed, anxious, and pale. She had some weakness in the hands and forearms but quite marked weakness in the legs. Tactile and pain sensation were intact but vibrătion and position sensations were lost in the lower limbs. Romberg's sign was positive. All the tendon jerks were brisk and the plantars were upgoing on both sides. Fundi, cranial nerves, and systemic examination revealed no other abnormalities. A clinical diagnosis of subacute combined degeneration of the
SIR,-Some two years ago expediency led us to employ a disposable Mantoux syringe, fitted with an appropriately fine needle, to collect vesicle fluid from a case of atypical varicella in which virological studies were felt necessary to exclude any possibility of variola. We were impressed both by the painless ease with which the vesicles could be punctured and by the good harvest of fluid. Prompted by this early success we have continued to use Mantoux syringes for this purpose and feel it is probably a 